\title{
Biomarkers and recent advances in the management and therapy of sickle cell disease [version 1; peer review: 2
}

\section{approved]}

\author{
Marilyn J. Telen
}

Duke University School of Medicine, Box 2615, Duke University Medical Center, Durham, NC, 27710, USA

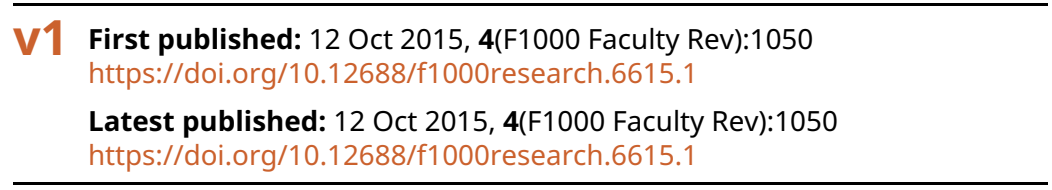

\section{Abstract}

Although production of hemoglobin $S$, the genetic defect that causes sickle cell disease (SCD), directly affects only red blood cells, the manifestations of SCD are pervasive, and almost every cell type and organ system in the body can be involved. Today, the vast majority of patients with SCD who receive modern health care reach adulthood thanks to vaccine prophylaxis and improvements in supportive care, including transfusion. However, once patients reach adulthood, they commonly experience recurrent painful vaso-occlusive crises and frequently have widespread end-organ damage and severely shortened life expectancies. Over the last several decades, research has elucidated many of the mechanisms whereby abnormal red blood cells produce such ubiquitous organ damage. With these discoveries have come new ways to measure disease activity. In addition, new pharmaceutical interventions are now being developed to address what has been learned about disease mechanisms.

Keywords

sickle cell, anemia, biomarkers, red blood cells
Open Peer Review

Approval Status

1

2

version 1

12 Oct 2015

Faculty Reviews are review articles written by the prestigious Members of Faculty Opinions. The articles are commissioned and peer reviewed before publication to ensure that the final, published version is comprehensive and accessible. The reviewers who approved the final version are listed with their names and affiliations.

1. James G. Taylor VI, National Institutes of Health, Bethesda, USA

2. Emily Meier, Children's National Medical Center, District of Columbia, USA

Any comments on the article can be found at the end of the article. 
Corresponding author: Marilyn J. Telen (marilyn.telen@duke.edu)

Competing interests: The author has received research support from GlycoMimetics (maker of GMI-1070) and Dilaforette (maker of sevuparin). She currently serves on the steering committee for the ongoing phase 3 trial of rivipansel sponsored by Pfizer.

Grant information: The author(s) declared that no grants were involved in supporting this work.

Copyright: @ 2015 Telen MJ. This is an open access article distributed under the terms of the Creative Commons Attribution License, which permits unrestricted use, distribution, and reproduction in any medium, provided the original work is properly cited.

How to cite this article: Telen MJ. Biomarkers and recent advances in the management and therapy of sickle cell disease [version

1; peer review: 2 approved] F1000Research 2015, 4(F1000 Faculty Rev):1050 https://doi.org/10.12688/f1000research.6615.1

First published: 12 Oct 2015, 4(F1000 Faculty Rev):1050 https://doi.org/10.12688/f1000research.6615.1 


\section{Introduction and context}

Although it has long been straightforward to define sickle cell disease (SCD) and its subtypes through biochemical and genetic analyses of hemoglobin and its encoding genes, understanding the pathophysiologic mechanisms leading to the disease's protean manifestations has been more challenging. After decades of research, a great deal has been learned about the many pathways and processes affected downstream by the hemoglobin $\mathrm{S}(\mathrm{HbS})$ mutation, and, finally, new therapeutic approaches targeting these mechanisms are being developed. Nevertheless, a lack of even a basic ability to document and follow the processes leading to vasoocclusive episodes persists. At this time, both the diagnosis of vasoocclusion and the definition of its resolution rely exclusively on patient reports of pain.

The difficulty in obtaining objectively measurable biomarkers of disease activity and variability hampers many aspects of the management of SCD, including (1) diagnosis of acute vaso-occlusion, acute chest syndrome, and other sequelae of SCD; (2) understanding of the inciting events leading to vaso-occlusion and its complications in SCD; (3) personalized medicine through identification of particularly suitable or unsuitable candidates or events for targeted disease therapies; and (4) documentation of new drug effects and mechanisms of action.

Despite the fact that the abnormal hemoglobin that defines SCD is expressed only in erythrocytes, all blood cells as well as soluble blood elements and most other organ systems are affected by SCD. Patients with SCD have, at baseline, elevated leukocyte and platelet counts, abnormally increased leukocyte and platelet activation, abnormal activation of coagulation pathways, increased expression of multiple inflammatory markers, increased expression of soluble markers of endothelial activation and injury, and increased markers associated with a broad range of end-organ damage.

Many such "biomarkers" have been studied either in "steady-state" SCD or during acute vaso-occlusive episodes, and some have been shown to correlate with long-term survival. In addition, because vasoocclusion may arise from a variety of inciting events (e.g., infection and physiologic stress), the mechanisms of vaso-occlusion may be variable among patients and vaso-occlusive events. Identification of biomarkers specific for processes contributing to vaso-occlusion could help determine which drugs might be most beneficial and might also elucidate the mechanism of action of new therapeutic agents. Biomarkers might also help determine when new therapeutic agents might be useful as prophylactic therapy to prevent progressive end-organ damage.

The past few decades, during which both mechanisms of vasoocclusion and biomarkers have been identified, have also brought the dawn of targeted therapies for vaso-occlusion. Although none has yet to be proven useful or become US Food and Drug Administration (FDA)-approved since approval of hydroxyurea (HU) for the prevention of vaso-occlusion and acute chest syndrome, several promising targeted agents are in various stages of clinical trials. Many such studies are also examining biomarkers, as they are affected by both vaso-occlusion and the new potential therapeutic agents. Thus, it is reasonable to expect that progress in therapeutics and in the discovery of useful biomarkers will go hand-in-hand in the future, leading potentially to both targeted and personalized therapy for SCD.

\section{Pathophysiology and biomarkers}

\section{Clinical measures and overall prognosis}

Early studies of the natural history of SCD, largely in children and young adults, identified several markers of disease severity and poorer overall survival ${ }^{1,2}$. Frequency of vaso-occlusive episodes was a marker of poorer survival in patients with sickle cell anemia (homozygous for $\mathrm{HbS}$ ) who were more than 20 years old $^{2}$. High rates of vaso-occlusive episodes were also associated with higher hematocrit and lower fetal hemoglobin levels in that study. A second study of largely the same patient population further revealed that acute chest syndrome, renal failure, seizures, a high baseline white cell count $\left(>15,000\right.$ cells $\left./ \mathrm{mm}^{2}\right)$, and low fetal hemoglobin were associated with an increased risk of early death; early mortality was again shown to be more frequent among the most symptomatic patients ${ }^{1}$. Finally, a more recent analysis of the cohort enrolled as newborns in the same study showed that more pronounced reticulocytosis increased the risk of stroke and mortality during childhood ${ }^{3}$.

More recent studies of factors associated with mortality in SCD have presumably reflected the era of HU therapy, and some have studied factors related to survival in different resource settings. Recent studies ${ }^{4-6}$ of adults have shown that more frequent episodes of vaso-occlusion remain a marker of increased mortality ${ }^{4,5}$, and sickle nephropathy is also a significant risk factor ${ }^{4-6}$. In addition, the presence of an elevated tricuspid regurgitant jet velocity (TRV) $(\geq 2.5 \mathrm{~m} / \mathrm{sec}$ ), with or without catheterization-proven pulmonary arterial hypertension, is a very significant risk factor for accelerated mortality ${ }^{4-8}$. A history of cumulative end-organ damage and stroke was also associated with earlier mortality ${ }^{5}$.

Interest in pulmonary hypertension and SCD has also spurred investigation of markers thought to be related to endothelial damage and inflammation. Of these, vascular cell adhesion molecule 1(VCAM-1) levels have been reproducibly associated with survival ${ }^{5,9}$.

Hemoglobin F (HbF) levels are often measured clinically, and several studies have supported the hypothesis that higher HbF levels lead to less severe SCD. HbF has higher oxygen affinity than $\mathrm{HbA}$ or $\mathrm{HbS}$, and sickle red cells containing more $\mathrm{HbF}$ survive longer in the circulation ${ }^{10}$. Moreover, elevation of $\mathrm{HbF}$ is a key (though not the only) factor in the salutary effects of HU on SCD severity ${ }^{11}$.

\section{Adhesion}

Sickle red cells are abnormally adherent to many substrates, including endothelial cells ${ }^{12}$, leukocytes ${ }^{13}$, platelets $^{14}$, and extracellular matrix molecules such as laminin ${ }^{13,15}$ and thrombospondin ${ }^{16,17}$. Hebbel and colleagues found evidence decades ago that patients with more adherent cells were more likely to suffer vaso-occlusive episodes $^{18}$. However, while such adhesion almost certainly contributes to vaso-occlusive pathogenesis, measuring adhesion either ex vivo or in vivo remains difficult. Thus, assays of cell adhesion are often used for research purposes but have not been extensively explored as markers of disease. 
Nevertheless, one measurable outcome of adhesion is the formation of circulating heterocellular aggregates that can be measured by flow cytometry, now a part of most clinical hospital laboratories. Sickle red cells, as well as leukocytes from patients with SCD, can be found in circulating aggregates involving both each other as well as platelets ${ }^{14,19}$. How such measures related to clinical status and outcomes in SCD remains to be better defined.

\section{Inflammation}

SCD is accompanied by a broad array of inflammatory processes. At steady state, in the absence of symptomatic vaso-occlusion, patients with SCD have increased numbers of activated leukocytes ${ }^{20}$, activated platelets, and formation of multicellular aggregates.

In addition, patients with SCD may have elevations of multiple inflammatory cytokines (Table 1), both in steady state as well as during vaso-occlusive events. Although not all studies demonstrate concordant findings, among the cytokines consistently found to be both elevated at steady state and then further elevated during vaso-occlusive events are interleukin-10 (IL-10), macrophage inflammatory protein $1 \alpha$ (MIP-1 $\alpha)$, placenta growth factor (PlGF), prostaglandin $\mathrm{E}_{2}\left(\mathrm{PGE}_{2}\right)$, and soluble CD40 ligand (sCD40L). Current investigations are focusing on how these cytokines can contribute to the pathophysiology of vaso-occlusion.

\section{Coagulation}

Coagulation pathways are broadly activated in patients with $\mathrm{SCD}^{21}$. Thus, SCD is considered a "hypercoagulable state", and indeed there is a higher prevalence of pregnancy-related thrombosis and pulmonary emboli in patients with SCD than in age-matched African-American controls ${ }^{22,23}$. Clinically, levels of D-dimer are often chronically elevated and increase further during vaso-occlusive events $^{24,25}$. Other biomarkers of activated coagulation, such as plasma levels of prothrombin fragment 1.2 (F1.2), thrombin-antithrombin (TAT) complexes, plasmin-antiplasmin complexes, and fibrinopeptide A, are also elevated in SCD. There is at least some evidence that the degree of elevation of D-dimer levels is predictive of the frequency of vaso-occlusive episodes ${ }^{26}$. Furthermore, the hypothesis that abnormal SCD red cells, and specifically those with increased phosphatidylserine (PS) exposure at their surfaces, are responsible for activation of coagulation is supported by the demonstration that the number of PS-positive sickle red cells is related to the degree of elevation of D-dimer, F1.2, and plasmin-antiplasmin complex levels ${ }^{27,28}$.

Investigators have also shown that there are elevated levels of tissue factor in the circulation in $\mathrm{SCD}^{29-31}$ and that platelets are also activated in greater numbers ${ }^{32,33}$. Blood from patients with SCD also contains increased levels of microparticles derived from multiple

Table 1. Expression of cytokines, acute-phase proteins, and inflammatory molecules in sickle cell disease.

\begin{tabular}{|c|c|c|c|}
\hline Cytokine or molecule & $\begin{array}{l}\text { Expression in steady-state } \\
\text { sickle cell disease }\end{array}$ & $\begin{array}{l}\text { Expression during vaso- } \\
\text { occlusion }\end{array}$ & References \\
\hline C-reactive protein & Increased & Can be further increased & 102,103 \\
\hline Interferon- $\gamma$ & Normal or increased & $\begin{array}{l}\text { Not further increased compared } \\
\text { with steady state }\end{array}$ & 104,105 \\
\hline Interleukin-1 $\beta$ & Normal or increased & Normal or increased & $104-107$ \\
\hline Interleukin-2 & Normal & Normal & 105 \\
\hline Interleukin-4 & Increased & $\begin{array}{l}\text { Not further increased compared } \\
\text { with steady state }\end{array}$ & 105 \\
\hline Interleukin-6 & Increased & Further increased & $102,104,105,107$ \\
\hline Interleukin-8 & Increased & $\begin{array}{l}\text { Variably further increased } \\
\text { compared with steady state }\end{array}$ & $104,105,107-109$ \\
\hline Interleukin-10 & Increased & Further increased & 104,107 \\
\hline $\begin{array}{l}\text { Monocyte chemoattractrant } \\
\text { protein-1 (MCP-1) }\end{array}$ & Variable & & 102,104 \\
\hline $\begin{array}{l}\text { Macrophage inflammatory } \\
\text { protein } 1 \alpha(\text { MIP- } 1 \alpha)\end{array}$ & Increased & Further increased & 104 \\
\hline Neuropeptide substance P (SP) & Increased & Further increased & 108 \\
\hline Pentraxin-3 (PTX3) & Normal & Increased & 50 \\
\hline Placental growth factor (PIGF) & Increased & Further increased & $110-113$ \\
\hline Prostaglandin $\mathrm{E}_{2}\left(\mathrm{PGE}_{2}\right)$ & Increased & Further increased & $107,109,114$ \\
\hline Soluble CD40L & Increased & Further increased & 91 \\
\hline Thrombospondin & Increased & Further increased & 111 \\
\hline Tumor necrosis factor- $\alpha$ & Normal or increased & Normal or increased & $102,104-107$ \\
\hline TNFSF14 (LIGHT) & Increased & & 115 \\
\hline
\end{tabular}


cell types, including red cells, platelets, leukocytes, and endothelial cells. Tissue factor-expressing microparticles appear to be derived primarily from monocytes and endothelial cells ${ }^{34}$. Finally, recent evidence suggests that free plasma iron may also contribute to activated coagulation in $\mathrm{SCD}^{35}$.

\section{Oxidant damage}

Oxidant damage appears to occur at an accelerated rate in SCD, both within the red cell as well as in other tissues. Hemolysis results in the release of hemoglobin, which itself is a powerful oxidant. In addition, several investigators have reported reduced anti-oxidant compounds both within sickle red cells as well as in plasma. Plasma lipid peroxidation is higher in SCD patients than controls, and red cell content of glutathione reductase and superoxide dismutase is lower in sickle erythrocytes ${ }^{36}$. Depletion of glutathione has been associated with elevated TRV, itself a biomarker for pulmonary hypertension and early mortality ${ }^{37}$. Finally, some evidence suggests that reduction in expression of genes responsible for the synthesis of anti-oxidant compounds may also contribute to worsening anemia in $\mathrm{SCD}^{38}$. HU has been found to reduce markers of oxidative stress in $\mathrm{SCD}^{39,40}$.

\section{Biomarkers and stroke}

Stroke is a common and potentially devastating problem in SCD, and strokes start to occur in very young children ${ }^{41}$. Once a stroke occurs, patients are at great risk for recurrent strokes, which can be largely prevented by chronic transfusion but have a high frequency of recurrence without continuing transfusion ${ }^{42}$. Transcranial Doppler (TCD) measurements have been known to provide a good measurement of the risk of stroke in children with SCD since 1992, when children with abnormal TCDs were shown to be at 44 times the risk for stroke than children with normal TCDs ${ }^{43}$. The Stroke Prevention Trial in Sickle Cell Anemia (STOP) showed that regular transfusion could reduce the risk of a first stroke by $92 \%$, compared with nontransfused children with abnormal TCDs, who had about a $10 \%$ incidence of stroke annually ${ }^{44}$. However, a subsequent study of children who had already undergone at least 30 months of transfusion for abnormal TCDs failed to show that such transfusion could be safely stopped $^{45}$. Thus, while TCDs are now standard of practice in pediatric care of SCD, in order to identify children at risk for primary strokes, they do not allow avoidance of transfusion for the relatively large number of children who would not ultimately have a stroke, despite their abnormal TCDs. Efforts to better define the at-risk population, such as through identification of genetic risk factors or other biomarkers, have not yet defined a solution to this problem.

\section{Biomarkers of acute chest syndrome}

Acute chest syndrome (ACS) is one of the most feared complications of vaso-occlusive episodes and is highly associated with mortality. Secretory phospholipase A(2) (sPLA(2)) levels become quite elevated in about $80 \%$ of patients with $\mathrm{ACS}^{46,47}$ and often become quite elevated shortly before patients become symptomatic ${ }^{47,48}$. Thrombospondin-1 levels have also been reported to become markedly increased in $\mathrm{ACS}^{49}$, as have levels of pentraxin- $3^{50}$. C-reactive protein has been reported to parallel SPLA(2) in the context of vasoocclusion and $\mathrm{ACS}^{51}$. At least one study has attempted to prevent ACS with transfusion in patients with high $\operatorname{sPLA}(2)$ levels $^{52}$, but a definitive study has not been conducted.

\section{Biomarkers and pulmonary hypertension}

Pulmonary hypertension has become recognized as a major risk factor for death in adults with $\mathrm{HbSS}$ and $\operatorname{HbS} \beta 0$ thalassemia ${ }^{8}$. However, the most widely available screening test for pulmonary hypertension-echocardiography - does not reliably reflect pulmonary arterial pressures, as measured by right heart catheterization. In fact, right heart catheterization may confirm pulmonary hypertension in only $10 \%$ to $25 \%$ of patients with elevated $\mathrm{TRV}^{53,54}$, giving echocardiography a positive predictive value of only $25 \%$ to $32 \%{ }^{55}$. Nevertheless, a TRV of over 2.5 to $3 \mathrm{~m} / \mathrm{sec}$ has been an indicator of risk for mortality in several studies ${ }^{6,7,56}$ despite its lack of reliability as an indicator of catheterization-measurable pulmonary arterial hypertension ${ }^{6}$. Thus, the recent National Institutes of Health guidelines for sickle cell anemia management did not recommend for or against routine echocardiographic screening for pulmonary hypertension in asymptomatic adults with $\mathrm{SCD}^{57}$. In addition, several studies have shown that elevated pro-brain natriuretic peptide (pro-BNP) is associated with a high risk of mortality, especially in combination with a TRV of at least $3 \mathrm{~m} / \mathrm{sec}^{6}$. VCAM-1, a marker of endothelial activation and damage, is also present at higher levels in SCD patients with pulmonary hypertension ${ }^{58}$. VCAM-1 is also reproducibly associated with poorer survival ${ }^{5,9}$.

\section{Biomarkers and therapeutic approaches}

Although the biomarkers discussed above do not represent the totality of biomarkers explored and found to be possibly informative in the context of SCD, they do point to the panoply of pathophysiologic mechanisms now appreciated as active in SCD. Adhesion, inflammation, coagulation, and oxidative damage are likely the most important, though not the only, contributors to the development of vaso-occlusion and organ damage in this disease. Moreover, we do not completely understand how the processes implicated by the evidence of biomarkers produce the varied physiologic events we observe. For example, SCD involves both large-vessel events (e.g., strokes) as well as occlusion of microvascular structures, which is believed to be involved in typical painful vaso-occlusive events. Nevertheless, current efforts to develop new therapies for $\mathrm{SCD}$ are concentrating on the processes reflected by the biomarkers discussed above. In the future, biomarkers may assist us in personalizing treatment according to the predominant mechanisms involved in a particular disease sequela or event.

\section{New and targeted drugs in development}

Since SCD was recognized and defined in the early 20th century, survival and quality of life have until recently improved primarily because of advances in supportive care, including penicillin prophylaxis, routine immunizations, transfusion for stroke and acute chest syndrome, and hydration and narcotic therapy for vasoocclusive episodes. This changed after the Multicenter Study of Hydroxyurea $^{59}$, which showed that HU reduced the frequency of both vaso-occlusive episodes and acute chest syndrome while increasing both total hemoglobin levels and hemoglobin F percentages and decreasing neutrophil counts. However, the study was not designed to, and did not, determine the mechanism whereby HU reduced vaso-occlusive and acute chest syndrome events. In this setting, the FDA approved the drug for use in adults with SCD in 1998. Subsequent studies have confirmed that the drug is cost-effective ${ }^{60}$ and improves long-term survival ${ }^{61-63}$. The drug has 
also proven to be safe and effective in children ${ }^{64,65}$. Nevertheless, the consensus remains that the drug is underutilized in both children and adults (http://consensus.nih.gov/2008/sicklecellstatement.htm). One recent study suggested that, outside a center dedicated to treating SCD, only about $25 \%$ of patients meeting the original study criteria actually receive $\mathrm{HU}^{66}$. Moreover, the mechanisms whereby HU has its beneficial effects remain only partly understood.

Not only have new therapies for SCD not arrived since HU gained FDA approval in 1998, but truly curative therapies have been difficult to achieve (Table 2). Hematopoietic stem cell transplantation and gene therapy offer the best chances for cure but each presents numerous challenges that have been difficult to overcome. Although there were initial successes in young pediatric patients, successful hematopoietic stem cell transplantation with good survival and tolerable graft-versus-host disease in adults proved much harder to achieve. Nevertheless, such transplants can now be confidently undertaken ${ }^{67-69}$, and many ongoing clinical trials are looking at ways to improve both engraftment and the availability of donors.

Gene therapy is an even more challenging but ultimately less toxic approach to achieving curative therapy for SCD. The general approach has been to develop methods for inserting into autologous hematopoietic stem cells either a gene encoding normal $\beta$-globin or a globin chain with anti-sickling properties, such as $\gamma$-globin (that leads to production of $\mathrm{HbF}$ ). Another approach that has been explored involves methodologies for "correcting" the faulty $\beta$-globin gene. These approaches, however, either are still in development or are in very early clinical trials.

\section{Inhibitors of cell activation and adhesion}

One of the most attractive therapeutic targets in SCD is cell adhesion. Although SCD severity was first linked to the degree of red cell adhesion exhibited by patients' red cells, it is now apparent that leukocyte and platelet activation and adhesion also contribute to pathophysiology. Therefore, cell adhesion has become a primary target for the development of new therapeutic approaches. In general, such approaches may involve inhibition of cell-cell interactions generally, specific inhibition of adhesion receptors, or interference with the signaling mechanisms that lead to activation of adhesion receptors.

Non-specific inhibition of cell adhesion by poloxamer-188 was studied in a multicenter randomized phase III trial involving both children and adults to determine its effect on duration of painful vaso-occlusive episodes. Although the results were statistically significant, differences in time to resolution of painful episodes were small but were slightly greater in children ${ }^{70}$. Another phase III study of this drug, using a somewhat different study design, is now under way (NCT01737814, ClinicalTrials.gov).

Another anti-adhesion therapeutic has been developed to address adhesive interactions involving primarily E-selectin. This drug (GMI-1070, now known as rivipansel) was quite successful in abrogating vaso-occlusion in sickle mice ${ }^{71}$. In a subsequent phase I study of SCD patients in steady state, rivipansel was well tolerated and appeared to improve blood flow in a subset of patients. Perhaps most interesting, however, was the drug's effect on biomarkers: the drug was associated with significant decreases in biomarkers of endothelial activation, including sE-selectin, sP-selectin, and soluble intercellular adhesion molecule-1 (sICAM). Markers of leukocyte activation and coagulation were also decreased ${ }^{72}$. A phase II study of the drug in patients experiencing painful vaso-occlusive episodes showed large and consistent decreases in all measures of time to crisis resolution, although these were not statistically significant. Moreover, opiate usage was markedly and statistically significantly decreased with drug versus placebo ${ }^{73}$. A phase III study is expected to be under way shortly (NCT02187003, ClinicalTrials.gov).

Other drugs, both new and old, also have potential anti-adhesive effects that could be useful in SCD. P-selectin is known to contribute to adhesion of both sickle red cells and leukocytes to endothelial cells $^{74-76}$, and heparins have both anti-P-selectin as well as anticoagulation effects ${ }^{75}$. In fact, heparin blocks P-selectin-mediated adhesion at levels considerably lower than those needed for anticoagulation ${ }^{77}$. A small phase 2 study of pentosan polysulfate sodium has shown promising results, in that a single oral dose improved microvascular blood flow, and repeated daily doses were associated with decreased plasma levels of soluble vascular cell adhesion molecule-1 (sVCAM-1) ${ }^{77}$. Another compound chemically related to low-molecular-weight heparin (LMWH), sevuparin (Dilaforette), has shown promising results in vitro and in vivo in a mouse model of vaso-occlusion ${ }^{78}$, and plans are under way to study the drug in SCD. Another P-selectin-targeted drug, SelG1 (Selexys Pharmaceuticals), is currently in clinical trial for use as a prophylactic agent to prevent vaso-occlusive crises (NCT01895361, ClinicalTrials.gov).

Finally, several studies in animals and patients have addressed the possibility that downregulation of signaling pathways may decrease cell adhesion. Several red cell adhesion receptors, including the $\mathrm{BCAM} / \mathrm{Lu}$ receptor for laminin ${ }^{79}$ and the ICAM-4 receptor for integrins ${ }^{80,81}$, are activated downstream of $\beta$-adrenergic receptor signaling pathways. Animal studies and a phase 1 trial of propranolol showed that propranolol decreased sickle red cell adhesion measured in vitro and decreased vaso-occlusion in mice in vivo ${ }^{81,82}$. In addition, the ERK signaling pathway appears to be involved in sickle red cell adhesion ${ }^{83,84}$, and the ability to affect this pathway via MEK inhibition is now being explored ${ }^{85}$.

\section{Anticoagulants}

Given the abundant data that coagulation pathways are abnormally activated in SCD, early studies explored the possibility that anticoagulation might have a beneficial effect in SCD, but most of those studies were too small or time-limited to be definitive. Using acenocoumarol, one study showed that achieving an international normalized ratio (INR) of 1.64 (range of 1.18-2.2) was associated with normalization of the F1 +2 level and therefore concluded that low-intensity oral anticoagulation could normalize the hypercoagulability in $\mathrm{SCD}^{86}$. Newer studies have again approached the potential usefulness of anticoagulation in SCD. A randomized double-blind clinical trial of an LMWH, tinzaparin, versus placebo was conducted during the management of acute painful vasoocclusive episodes. This 253-patient study administered tinzaparin subcutaneously at $175 \mathrm{IU} / \mathrm{kg}$ once daily, along with usual supportive care and analgesia. Although the endpoints and criteria for 
Table 2. New therapeutic approaches under investigation or recently investigated for sickle cell disease.

\begin{tabular}{|c|c|c|}
\hline Classification and agent & Rationale/Goal & ClinicalTrials.gov registration \\
\hline $\begin{array}{l}\text { Hematopoietic stem cell } \\
\text { transplantation }\end{array}$ & $\begin{array}{l}\text { Replace stem cells leading to production of } \mathrm{HbS} \text { with cells } \\
\text { that produce either normal or anti-sickling } \mathrm{Hb} \text { (such as } \mathrm{HbF} \text { ) }\end{array}$ & $\begin{array}{l}00408447,01461837,00977691 \\
01877837,02065596, \text { and } 00152113\end{array}$ \\
\hline Gene transfer or correction & $\begin{array}{l}\text { Replace or correct the } \mathrm{HbS} \text { gene with a gene encoding either } \\
\text { normal or anti-sickling } \mathrm{Hb} \text { (such as } \mathrm{HbF} \text { ) }\end{array}$ & 02186418,02140554 , and 02151526 \\
\hline \multicolumn{3}{|l|}{ Nutritional supplements } \\
\hline - L-glutamine & Lower energy requirements to improve growth and strength & $\begin{array}{l}01179217,00131508,00586209 \\
\text { and } 00125788\end{array}$ \\
\hline - Niacin & Improve blood flow & 00508989 \\
\hline - Vitamin D & $\begin{array}{l}\text { Correct chronic vitamin D deficiency common in children with } \\
\text { SCD }\end{array}$ & 01276587 \\
\hline $\begin{array}{l}\text { - Alpha-lipoic acid and } \\
\text { acetyl-L-carnitine }\end{array}$ & Anti-oxidant & 01054768 \\
\hline - Arginine & Improve availability of NO & 00513617 \\
\hline \multicolumn{3}{|l|}{ Anti-inflammatory } \\
\hline - Regadenoson & Downregulate the activity of iNKT cells & 01566890 and 01085201 \\
\hline - NKTT120 & Deplete iNKT cells & 01783691 \\
\hline - Zileuton & Reduce inflammation & 01136941 \\
\hline - Montelukast & Reduce soluble vascular cell adhesion molecule-1 (sVCAM-1) & 01960413 \\
\hline - IVIg & Shorten VOC & 01757418 \\
\hline \multicolumn{3}{|l|}{ Anti-adhesive } \\
\hline - Propranolol & $\begin{array}{l}\text { Reduce activation of red cell adhesion receptors activated via } \\
\text { beta adrenergic receptor signaling pathways }\end{array}$ & 01077921 and 02012777 \\
\hline - SelG1 & Block adhesion via P-selectin to prevent VOC episodes & 01895361 \\
\hline - PF-04447943 & Phosphodiesterase-9 inhibitor & 02114203 \\
\hline - Rivipansel & Reduce adhesion and inflammation dependence on E-selectin & 01119833 and 02187003 \\
\hline \multicolumn{3}{|l|}{ Anti-sickling } \\
\hline - $\mathrm{MP} 4 \mathrm{CO}$ & Reduce sickling by delivering $\mathrm{CO}$ & 01356485 \\
\hline - SCD-101 & Reduce sickling & 02380079 \\
\hline - Sanguinate (PEG-bHb-CO) & Reduce sickling by delivering $\mathrm{CO}$ & 01848925 \\
\hline - AES-103 & Reduce sickling & 01987908 \\
\hline \multicolumn{3}{|l|}{ Alter hemoglobin expression } \\
\hline - Vorinostat & Increase $\mathrm{HbF}$ & 01000155 \\
\hline - HU with Mg Pidolate & Increase both $\mathrm{HbF}$ and cell hydration & 00143572 \\
\hline - HQK-1001 & Increase $\mathrm{HbF}$ & 01601340 \\
\hline - Panibostat & Increase $\mathrm{HbF}$ & 01245179 \\
\hline - Decitabine & Increase $\mathrm{HbF}$ & 01375608 and 01685515 \\
\hline - Pomalidomide & Increase HbF & 0522547 \\
\hline \multicolumn{3}{|l|}{ Anti-coagulant and anti-platelet } \\
\hline - Ticagrelor & Decrease vaso-occlusive episodes and pain & 02214121 \\
\hline - Prasugrel & Decrease vaso-occlusive episodes and pain & 01167023,01794000, and 01476696 \\
\hline - N-acetyl cysteine & $\begin{array}{l}\text { Decrease VWF levels, VWF total activity, ULVWF multimers, } \\
\text { and VWF functions }\end{array}$ & 01800526 \\
\hline - Aspirin & $\begin{array}{l}\text { Diminish the incidence and progression of cognitive deficits } \\
\text { as well as occurrence of overt and silent stroke }\end{array}$ & 00178464 \\
\hline - Eptifibatide & $\begin{array}{l}\text { Reduce platelet activation and release of pro-inflammatory } \\
\text { cytokines }\end{array}$ & 00834899 \\
\hline
\end{tabular}




\begin{tabular}{|c|c|c|}
\hline Classification and agent & Rationale/Goal & ClinicalTrials.gov registration \\
\hline \multicolumn{3}{|l|}{ Other } \\
\hline - Inhaled NO & Improve pulmonary hypertension & 00023296 \\
\hline - ICA-17043 & Reduce hemolysis and VOC by increased cell hydration & 00040677 \\
\hline - Intravenous NO & Vaso-dilation & 00095472 \\
\hline - Losartan & Improve SCD nephropathy & 02373241 \\
\hline $\begin{array}{l}\text { - } 6 \mathrm{R}-\mathrm{BH} 4 \text { (sapropterin } \\
\text { dihydrochloride) }\end{array}$ & Improve endothelial dysfunction & 00445978, 00403494, and 00532844 \\
\hline - Magnesium sulfate & Reduce length of stay and pain in children with acute VOC & 00313963 \\
\hline - Varespladib (A-001) & Decrease acute chest syndrome & 01522196 and 00434473 \\
\hline - Atorvastatin & Improve endothelial dysfunction & 00072826 \\
\hline - Simvastatin & Improve endothelial dysfunction & 00508027 \\
\hline - Bosentan & Improve pulmonary hypertension & 00313196, 00360087, and 00310830 \\
\hline - Clotrimazole & Reduce hemolysis and anemia by blocking Gardos channel & 00004404 and 00004492 \\
\hline
\end{tabular}

$\mathrm{CO}$, carbon monoxide; Hb, hemoglobin; HbF, hemoglobin F; HbS, hemoglobin S; HU, hydroxyurea; iNKT, invariant natural killer T; NO, nitric oxide; SCD, sickle cell disease; ULVWF, ultra-large von Willebrand factor; VOC, vaso-occlusive crisis; VWF, von Willebrand factor.

discharge were different from those usually used in the United States and other Western countries, analysis demonstrated a statistically significant reduction in several measures of time to resolution ${ }^{87}$. Another double-blind prospective study randomized SCD patients hospitalized for pain episodes to receive prophylactic LMWH (dalteparin 5,000 IU subcutaneously daily) or placebo. Although this study did not meet its target enrollment, the group receiving dalteparin had a greater decrease in pain scores at day 3 than did the placebo group (NCT01419977, ClinicalTrials.gov), although these results are unpublished to date. Another study used low-dose warfarin during vaso-occlusive crisis and studied D-dimer levels as their primary endpoint. They found that patients on warfarin had significantly lower D-dimer levels than patients not receiving the drug ${ }^{88}$; however, effects on clinical endpoints, such as time to resolution of painful episode, were not reported. Finally, another study of acenocoumarol showed that treatment to INR values of 1.6 to 2 failed to lower the plasma levels of endothelial activation markers in $\mathrm{SCD}^{89}$, raising questions about the likely clinical utility of anticoagulation to prevent SCD-related vascular events. Nevertheless, studies of the newer direct factor $\mathrm{X}$ inhibitors (apixaban and rivaroxaban) are currently planned or ongoing (NCT02179177 and NCT02072668, respectively, ClinicalTrials.gov). In addition, a study is under way to determine the feasibility of performing a larger multicenter phase III trial to assess the effects of unfractionated heparin in acute chest syndrome (NCT02098993, ClinicalTrials.gov).

Anti-platelet agents have also received attention and continue to be studied in the context of SCD. Eptifibatide is an anti-platelet agent that binds to the $\alpha \mathrm{IIb} \beta \mathrm{III}$ integrin on platelets and decreased in platelet aggregation and SCD40L levels in patients with SCD in a phase I study ${ }^{90}$. sCD40L is a pro-inflammatory cytokine released by platelets and chronically elevated in SCD plasma ${ }^{91}$. However, use of eptifibatide in a small pilot study showed that eptifibatide did not improve the times to crisis resolution or hospital discharge ${ }^{92}$. Another anti-platelet agent being studied in SCD is prasugrel. Recently, a multicenter phase 2 study of prasugrel versus placebo in adult patients with SCD showed that the drug could be safely used, and although it did not achieve statistically significant reductions in pain scores, it did reduce both platelet surface P-selectin and plasma soluble P-selectin levels, compared with placebo $^{93}$.

\section{Anti-inflammatory agents}

Inflammatory pathways in SCD are both the result of red and white cell adhesion to endothelial cells and to each other as well as promoters of such adhesion. In addition, transient vaso-occlusion leads to hypoxia/reperfusion injury with a robust inflammatory component. Therefore, targeting inflammatory pathways is a rational approach to treating or trying to prevent vaso-occlusion in SCD. Corticosteroids have been investigated but with mixed results. Newer therapies are now addressing the role of invariant natural killer T (iNKT) cells, which are known to play an important role in ischemia/reperfusion injury and which are increased in both number and activity in $\mathrm{SCD}^{94}$. In sickle mice, inhibition of iNKT cell activity with regadenoson, an adenosine A2A receptor agonist, led to a reduction in pulmonary inflammation and injury ${ }^{94}$. A phase 1 study in patients also showed promising results, including reduction in phospho-NF-kappa-B p65 activation in iNKT cells, compared with pretreatment baseline during vaso-occlusion ${ }^{95}$. The phase 2 study of regadenoson for treatment of vaso-occlusion is ongoing (NCT01788631, ClinicalTrials.gov). Another drug targeting iNKT cells is NKTT 120, a humanized monoclonal antibody against iNKT cells. After an initial study indicating safety, further ascending-dose phase 1 studies are being conducted to evaluate the safety, pharmacokinetics, pharmacodynamics, and biologic activity of the drug (NCT01783691, ClinicalTrials.gov). 


\section{Other therapeutic approaches}

Although the salutary effect of HU on SCD may be due to a more complex mechanism than its ability to raise HbF levels in about $50 \%$ of patients, it is also clear that not everyone responds to $\mathrm{HU}$ either clinically or with appreciably higher $\mathrm{HbF}$ levels. Therefore, other ways to increase $\mathrm{HbF}$ continue to be explored. Early studies showed that decitabine could substantially increase $\mathrm{HbF}$ levels in HU-non-responders ${ }^{96}$ and that such increased $\mathrm{HbF}$ levels were sustainable with repeated intermittent treatment ${ }^{97}$. Decitabine continues to be studied, both alone (NCT01375608, ClinicalTrials.gov) and in combination with tetrahydrouridine, a competitive inhibitor of cytidine deaminase that is being studied in an effort to improve oral bioavailability of decitabine ${ }^{98}$ (NCT01685515, ClinicalTrials.gov). Other agents that are being studied for their effects on HbF levels include panobinostat, vorinostat, pomalidomide, arginine butyrate, and HQK-1001 (2,2-dimethylbutyrate) ${ }^{99-101}$. However, in a phase 2 study, HQK-1001 was associated with only a modest $\mathrm{HbF}$ response and a paradoxical increase in vaso-occlusive episodes ${ }^{101}$.

\section{Implications for the future}

The complexity of the pathogenesis of SCD has resulted in a plethora of potential druggable targets in our effort to ameliorate the disease's sequelae. However, this same complexity has also prevented us from knowing which targets are optimal ones. Biomarkers may be helpful in patient selection for both research studies or therapy, but proof that changes in biomarkers are associated with clinical improvement remains elusive in most instances. Therefore, until we achieve wide availability of curative therapies through either hematopoietic stem cell transplantation or gene therapy, we need to continue our search for therapies that can be provided either to prevent or treat acute disease manifestations, such as vaso-occlusive pain, and chronic organ damage, such as sickle cell nephropathy and pulmonary hypertension. These goals, however, are still not quite within reach.

\section{Competing interests}

The author has received research support from GlycoMimetics (maker of GMI-1070) and Dilaforette (maker of sevuparin). She currently serves on the steering committee for the ongoing phase 3 trial of rivipansel sponsored by Pfizer.

\section{Grant information}

The author(s) declared that no grants were involved in supporting this work.
1. Platt OS, Brambilla DJ, Rosse WF, et al.: Mortality in sickle cell disease. Life expectancy and risk factors for early death. New Eng J Med. 1994; 330(23): 1639-1644.

PubMed Abstract | Publisher Full Text

2. Platt OS, Thorington BD, Brambilla DJ, et al:: Pain in sickle cell disease. Rates and risk factors. New Eng J Med. 1991; 325(1): 11-16.

PubMed Abstract | Publisher Full Text

3. F Meier ER, Wright EC, Miller JL: Reticulocytosis and anemia are associated with an increased risk of death and stroke in the newborn cohort of the Cooperative Study of Sickle Cell Disease. Am J Hematol. 2014; 89(9): 904-906. PubMed Abstract | Publisher Full Text | Free Full Text | F1000 Recommendation

4. $\quad$ F Darbari DS, Wang Z, Kwak M, et al.: Severe painful vaso-occlusive crises and mortality in a contemporary adult sickle cell anemia cohort study. PLoS One. 2013; 8(11): e79923.

PubMed Abstract | Publisher Full Text | Free Full Text | F1000 Recommendation

5. Elmariah $\mathrm{H}$, Garrett ME, De Castro LM, et al:: Factors associated with survival in a contemporary adult sickle cell disease cohort. Am J Hematol. 2014; 89(5): 530-535.

PubMed Abstract | Publisher Full Text | Free Full Text

6. F Gladwin MT, Barst RJ, Gibbs JS, et al.: Risk factors for death in $\mathbf{6 3 2}$ patients with sickle cell disease in the United States and United Kingdom. PLoS One. 2014; 9(7): e99489.

PubMed Abstract | Publisher Full Text | Free Full Text | F1000 Recommendation

7. De Castro LM, Jonassaint JC, Graham FL, et al:: Pulmonary hypertension associated with sickle cell disease: clinical and laboratory endpoints and disease outcomes. Am J Hematol. 2008; 83(1): 19-25.

PubMed Abstract | Publisher Full Text

8. Klings ES, Machado RF, Barst RJ, et al.: An official American Thoracic Society clinical practice guideline: diagnosis, risk stratification, and management of pulmonary hypertension of sickle cell disease. Am J Respir Crit Care Med. 2014; 189(6): 727-740.

PubMed Abstract | Publisher Full Text | Free Full Text

9. Kato GJ, Martyr S, Blackwelder WC, et al.: Levels of soluble endothelium-derived adhesion molecules in patients with sickle cell disease are associated with pulmonary hypertension, organ dysfunction, and mortality. Br J Haematol. 2005; 130(6): 943-953.

PubMed Abstract | Publisher Full Text | Free Full Text

10. Charache S: Fetal hemoglobin, sickling, and sickle cell disease. Adv Pediatr. 1990; 37: 1-31.

PubMed Abstract
11. Charache S, Dover GJ, Moore RD, et al:: Hydroxyurea: effects on hemoglobin F production in patients with sickle cell anemia. Blood. 1992; 79(10): 2555-2565.

PubMed Abstract

12. Hebbel RP, Boogaerts MA, Eaton JW, et al:: Erythrocyte adherence to endothelium in sickle-cell anemia. A possible determinant of disease severity. New Eng J Med. 1980; 302(18): 992-995. PubMed Abstract | Publisher Full Text

13. Zennadi $R$, De Castro $L$, Eyler $C$, et al.: Role and regulation of sickle red cell interactions with other cells: ICAM-4 and other adhesion receptors.

Transfus Clin Biol. 2008; 15(1-2): 23-28.

PubMed Abstract | Publisher Full Text

14. Wun $\mathrm{T}$, Paglieroni $\mathrm{T}$, Field $\mathrm{CL}$, et al.: Platelet-erythrocyte adhesion in sickle cel disease. J Investig Med. 1999; 47(3): 121-127. PubMed Abstract

15. Udani $\mathrm{M}$, Zen $\mathrm{Q}$, Cottman $\mathrm{M}$, et al:: Basal cell adhesion molecule/lutheran protein. The receptor critical for sickle cell adhesion to laminin. J Clin Invest. 1998; 101(11): 2550-2558.

PubMed Abstract | Publisher Full Text | Free Full Text

16. Brittain JE, Mlinar KJ, Anderson CS, et al.: Activation of sickle red blood cell adhesion via integrin-associated protein/CD47-induced signal transduction. $J$ Clin Invest. 2001; 107(12): 1555-1562. PubMed Abstract | Publisher Full Text | Free Full Text

17. Brittain JE, Mlinar KJ, Anderson CS, et al.: Integrin-associated protein is an adhesion receptor on sickle red blood cells for immobilized thrombospondin. Blood. 2001; 97(7): 2159-2164.

PubMed Abstract | Publisher Full Text

18. Hebbel RP, Boogaerts MA, Koresawa S, et al:: Erytrocyte adherence to endothelium as a determinant of vasocclusive severity in sickle cell disease. Trans Assoc Am Physicians. 1980; 93: 94-99. PubMed Abstract

19. $\mathrm{F}$ Brittain JE, Knoll CM, Ataga $\mathrm{KI}$, et al: Fibronectin bridges monocytes and reticulocytes via integrin alpha4beta1. Br J Haematol. 2008; 141(6): 872-881. PubMed Abstract | Publisher Full Text | F1000 Recommendation

20. Lum AF, Wun $T$, Staunton $D$, et al.: Inflammatory potential of neutrophils detected in sickle cell disease. Am J Hematol. 2004; 76(2): 126-133. PubMed Abstract | Publisher Full Text

21. Ataga KI, Key NS: Hypercoagulability in sickle cell disease: new approaches to an old problem. Hematology Am Soc Hematol Educ Program. 2007; 91-96. PubMed Abstract | Publisher Full Text 
22. Stein PD, Beemath A, Meyers FA, et al.: Deep venous thrombosis and pulmonary embolism in hospitalized patients with sickle cell disease. Am J Med. 2006; 119(10): 897.e897-811.

PubMed Abstract | Publisher Full Text

23. James AH, Jamison MG, Brancazio LR, et al.: Venous thromboembolism during pregnancy and the postpartum period: incidence, risk factors, and mortality. Am J Obstet Gynecol. 2006; 194(5): 1311-1315.

PubMed Abstract | Publisher Full Text

24. Devine DV, Kinney TR, Thomas PF, et al.: Fragment D-dimer levels: an objective marker of vaso-occlusive crisis and other complications of sickle cell disease. Blood. 1986; 68(1): 317-319.

PubMed Abstract

25. Francis RB Jr: Elevated fibrin $D$-dimer fragment in sickle cell anemia: evidence for activation of coagulation during the steady state as well as in painful crisis. Haemostasis. 1989; 19(2): 105-111. PubMed Abstract | Publisher Full Text

26. Tomer A, Harker LA, Kasey S, et al.: Thrombogenesis in sickle cell disease. $J$ Lab Clin Med. 2001; 137(6): 398-407. PubMed Abstract | Publisher Full Text

27. Setty BN, Kulkarni S, Rao AK, et al:: Fetal hemoglobin in sickle cell disease: relationship to erythrocyte phosphatidylserine exposure and coagulation activation. Blood. 2000; 96(3): 1119-1124. PubMed Abstract

28. Setty BN, Rao AK, Stuart MJ: Thrombophilia in sickle cell disease: the red cell connection. Blood. 2001; 98(12): 3228-3233.

PubMed Abstract | Publisher Full Text

29. Mohan JS, Lip GY, Wright J, et al:: Plasma levels of tissue factor and soluble E-selectin in sickle cell disease: relationship to genotype and to inflammation. Blood Coagul Fibrinolysis. 2005; 16(3): 209-214. PubMed Abstract

30. Setty BN, Key NS, Rao AK, et al:: Tissue factor-positive monocytes in children with sickle cell disease: correlation with biomarkers of haemolysis. Br J Haematol. 2012; 157(3): 370-380. PubMed Abstract | Publisher Full Text | Free Full Text

31. Sparkenbaugh EM, Chantrathammachart $P$, Wang $S$, et al.: Excess of heme induces tissue factor-dependent activation of coagulation in mice. Haematologica. 2015; 100(3): 308-314. PubMed Abstract | Publisher Full Text | Free Full Text

32. Westwick J, Watson-Williams EJ, Krishnamurthi S, et al.: Platelet activation during steady state sickle cell disease. J Med. 1983; 14(1): 17-36. PubMed Abstract

33. Triadou P, Fonty E, Ambrosio AS, et al:: Platelet function in sickle cell disease during steady state. Nouv Rev Fr Hematol. 1990; 32(2): 137-142. PubMed Abstract

34. Shet AS, Aras O, Gupta K, et al.: Sickle blood contains tissue factor-positive microparticles derived from endothelial cells and monocytes. Blood 2003; 102(7): 2678-2683.

PubMed Abstract | Publisher Full Text

35. F Shah N, Welsby IJ, Fielder MA, et al.: Sickle cell disease is associated with iron mediated hypercoagulability. J Thromb Thrombolysis. 2015; 40(2): 182-185. PubMed Abstract | Publisher Full Text | F1000 Recommendation

36. F Rusanova I, Escames G, Cossio G, et al:: Oxidative stress status, clinica outcome, and $\beta$-globin gene cluster haplotypes in pediatric patients with sickle cell disease. Eur J Haematol. 2010; 85(6): 529-537. PubMed Abstract | Publisher Full Text | F1000 Recommendation

37. Morris $\mathrm{CR}$, Suh $\mathrm{JH}$, Hagar W, et al.: Erythrocyte glutamine depletion, altered redox environment, and pulmonary hypertension in sickle cell disease. Blood. 2008; 111(1): 402-410.

PubMed Abstract | Publisher Full Text | Free Full Text

38. Sangokoya C, Telen MJ, Chi JT: microRNA miR-144 modulates oxidative stress tolerance and associates with anemia severity in sickle cell disease. Blood. 2010; 116(20): 4338-4348.

PubMed Abstract | Publisher Full Text | Free Full Text

39. F Silva DG, Belini Junior E, Torres Lde S, et al.: Relationship between oxidative stress, glutathione S-transferase polymorphisms and hydroxyurea treatment in sickle cell anemia. Blood Cells Mol Dis. 2011; 47(1): 23-28. PubMed Abstract | Publisher Full Text | F1000 Recommendation

40. F Torres Lde S, da Silva DG, Belini Junior E, et al:: The influence of hydroxyurea on oxidative stress in sickle cell anemia. Rev Bras Hematol Hemoter. 2012; 34(6): 421-425.

PubMed Abstract | Publisher Full Text | Free Full Text | F1000 Recommendation

41. Powars D, Wilson B, Imbus C, et al.: The natural history of stroke in sickle cell disease. Am J Med. 1978; 65(3): 461-471. PubMed Abstract | Publisher Full Text

42. Wang WC, Kovnar EH, Tonkin IL, et al:: High risk of recurrent stroke after discontinuance of five to twelve years of transfusion therapy in patients with sickle cell disease. J Pediatr. 1991; 118(3): 377-382. PubMed Abstract | Publisher Full Text

43. Adams RJ, Nichols FT, Figueroa R, et al: Transcranial Doppler correlation with cerebral angiography in sickle cell disease. Stroke. 1992; 23(8): 1073-1077. PubMed Abstract | Publisher Full Text
44. Adams RJ, McKie VC, Hsu L, et al.: Prevention of a first stroke by transfusions in children with sickle cell anemia and abnormal results on transcranial Doppler ultrasonography. N Engl J Med. 1998; 339(1): 5-11.

PubMed Abstract | Publisher Full Text

45. Adams RJ, Brambilla D; Optimizing Primary Stroke Prevention in Sickle Cell Anemia (STOP 2) Trial Investigators: Discontinuing prophylactic transfusions used to prevent stroke in sickle cell disease. N Engl J Med. 2005; 353(26): 2769-2778. PubMed Abstract | Publisher Full Text

46. Ballas SK, Files B, Luchtman-Jones L, et al:: Secretory phospholipase $\mathbf{A}_{2}$ levels in patients with sickle cell disease and acute chest syndrome. Hemoglobin. 2006; 30(2): 165-170.

PubMed Abstract | Publisher Full Text

47. Styles LA, Aarsman AJ, Vichinsky EP, et al:: Secretory phospholipase $\mathbf{A}_{2}$ predicts impending acute chest syndrome in sickle cell disease. Blood. 2000; 96(9): 3276-3278.

PubMed Abstract

48. Naprawa JT, Bonsu BK, Goodman DG, et al:: Serum biomarkers for identifying acute chest syndrome among patients who have sickle cell disease and present to the emergency department. Pediatrics. 2005; 116(3): e420-425. PubMed Abstract | Publisher Full Text

49. F Novelli EM, Kato GJ, Ragni MV, et al:: Plasma thrombospondin-1 is increased during acute sickle cell vaso-occlusive events and associated with acute chest syndrome, hydroxyurea therapy, and lower hemolytic rates. Am J Hematol. 2012; 87(3): 326-330.

PubMed Abstract | Publisher Full Text | Free Full Text | F1000 Recommendation

50. F Elshazly SA, Heiba NM, Abdelmageed WM: Plasma PTX3 levels in sickle cell disease patients, during vaso occlusion and acute chest syndrome (data from Saudi population). Hematology. 2014; 19(1): 52-59.

PubMed Abstract | Publisher Full Text | F1000 Recommendation

51. Bargoma EM, Mitsuyoshi JK, Larkin SK, et al: Serum C-reactive protein parallels secretory phospholipase $A_{2}$ in sickle cell disease patients with vasoocclusive crisis or acute chest syndrome. Blood. 2005; 105(8): 3384-3385. PubMed Abstract | Publisher Full Text

52. Styles LA, Abboud M, Larkin S, et al:: Transfusion prevents acute chest syndrome predicted by elevated secretory phospholipase $\mathbf{A}_{2}$. Br J Haematol. 2007; 136(2): 343-344

PubMed Abstract | Publisher Full Text

53. F Fonseca GH, Souza R, Salemi VM, et al.: Pulmonary hypertension diagnosed by right heart catheterisation in sickle cell disease. Eur Respir J. 2012; 39(1): 112-118.

PubMed Abstract | Publisher Full Text | F1000 Recommendation

54. F Parent $\mathrm{F}$, Bachir D, Inamo J, et al:: A hemodynamic study of pulmonary hypertension in sickle cell disease. N Engl J Med. 2011; 365(1): 44-53. PubMed Abstract | Publisher Full Text | F1000 Recommendation

55. Simonneau G, Parent F: Pulmonary hypertension in patients with sickle cell disease: not so frequent but so different. Eur Respir J. 2012; 39(1): 3-4. PubMed Abstract | Publisher Full Text

56. Ataga $\mathrm{KI}$, Moore CG, Jones $\mathrm{S}$, et al.: Pulmonary hypertension in patients with sickle cell disease: a longitudinal study. Br J Haematol. 2006; 134(1): $109-115$

PubMed Abstract | Publisher Full Text

57. F Yawn BP, Buchanan GR, Afenyi-Annan AN, et al:: Management of sickle cell disease: summary of the 2014 evidence-based report by expert panel members. JAMA. 2014; 312(10): 1033-1048.

PubMed Abstract | Publisher Full Text | F1000 Recommendation

58. Ataga $\mathrm{KI}$, Moore CG, Hillery CA, et al:: Coagulation activation and inflammation in sickle cell disease-associated pulmonary hypertension. Haematologica. 2008; 93(1): 20-26.

PubMed Abstract | Publisher Full Text

59. Charache S, Barton FB, Moore RD, et al:: Hydroxyurea and sickle cell anemia. Clinical utility of a myelosuppressive "switching" agent. The Multicenter Study of Hydroxyurea in Sickle Cell Anemia. Medicine (Baltimore). 1996; 75(6): 300-326.

PubMed Abstract | Publisher Full Text

60. Moore RD, Charache S, Terrin ML, et al:: Cost-effectiveness of hydroxyurea in sickle cell anemia. Investigators of the Multicenter Study of Hydroxyurea in Sickle Cell Anemia. Am J Hematol. 2000; 64(1): 26-31.

PubMed Abstract | Publisher Full Text

61. Steinberg $\mathrm{MH}$, Barton $\mathrm{F}, \mathrm{Castro} \mathrm{O}$, et al.: Effect of hydroxyurea on mortality and morbidity in adult sickle cell anemia: risks and benefits up to 9 years of treatment. JAMA. 2003; 289(13): 1645-1651.

PubMed Abstract | Publisher Full Text

62. F Steinberg MH, McCarthy WF, Castro O, et al:: The risks and benefits of ong-term use of hydroxyurea in sickle cell anemia: A 17.5 year follow-up. Am J Hematol. 2010; 85(6): 403-408.

PubMed Abstract | Publisher Full Text | Free Full Text | F1000 Recommendation

63. F Voskaridou E, Christoulas D, Bilalis A, et al:: The effect of prolonged administration of hydroxyurea on morbidity and mortality in adult patients with sickle cell syndromes: results of a 17-year, single-center trial (LaSHS) Blood 2010; 115(12): 2354-2363.

PubMed Abstract | Publisher Full Text | F1000 Recommendation 
64. F Wang WC, Ware RE, Miller ST, et al.: Hydroxycarbamide in very young children with sickle-cell anaemia: a multicentre, randomised, controlled tria (BABY HUG). Lancet. 2011; 377(9778): 1663-1672.

PubMed Abstract | Publisher Full Text | Free Full Text | F1000 Recommendation

65. F Thornburg CD, Files BA, Luo Z, et al:: Impact of hydroxyurea on clinical Fents in the BABY HUG trial. Blood. 2012; 120(22): 4304-4310. quiz 4448. PubMed Abstract | Publisher Full Text | Free Full Text | F1000 Recommendation

66. F Stettler N, McKiernan CM, Melin CQ, et al.: Proportion of adults with sickle cell anemia and pain crises receiving hydroxyurea. JAMA. 2015; 313(16): 1671-1672.

PubMed Abstract | Publisher Full Text | F1000 Recommendation

67. Horwitz ME, Spasojevic I, Morris A, et al:: Fludarabine-based nonmyeloablative stem cell transplantation for sickle cell disease with and without renal failure: clinical outcome and pharmacokinetics. Biol Blood Marrow Transplant. 2007; 13(12): 1422-1426.

PubMed Abstract | Publisher Full Text | Free Full Text

68. F Hsieh MM, Fitzhugh CD, Weitzel RP, et al.: Nonmyeloablative HLA-matched sibling allogeneic hematopoietic stem cell transplantation for severe sickle cell phenotype. JAMA. 2014; 312(1): 48-56.

PubMed Abstract | Publisher Full Text | F1000 Recommendation

69. F Hsieh MM, Kang EM, Fitzhugh CD, et al:: Allogeneic hematopoietic stem-cell ransplantation for sickle cell disease. N Engl J Med. 2009; 361(24): 2309-2317. PubMed Abstract | Publisher Full Text | Free Full Text | F1000 Recommendation

70. Orringer EP, Casella JF, Ataga KI, et al.: Purified poloxamer 188 for treatment of acute vaso-occlusive crisis of sickle cell disease: A randomized controlled trial. JAMA. 2001; 286(17): 2099-2106.

PubMed Abstract | Publisher Full Tex

71. F Chang J, Patton JT, Sarkar A, et al.: GMI-1070, a novel pan-selectin antagonist, reverses acute vascular occlusions in sickle cell mice. Blood. 2010; 116(10): 1779-1786.

PubMed Abstract | Publisher Full Text | Free Full Text | F1000 Recommendation

72. Wun T, Styles L, DeCastro L, et al.: Phase 1 study of the E-selectin inhibitor GMI 1070 in patients with sickle cell anemia. PLoS One. 2014; 9(7): e101301. PubMed Abstract | Publisher Full Text | Free Full Text

73. F Telen MJ, Wun T, McCavit TL, et al.: Randomized phase 2 study of GMI-1070 in SCD: reduction in time to resolution of vaso-occlusive events and decreased opioid use. Blood. 2015; 125(17): 2656-2664.

PubMed Abstract | Publisher Full Text | Free Full Text | F1000 Recommendation

74. Embury SH, Matsui NM, Ramanujam S, et al:: The contribution of endothelial cell P-selectin to the microvascular flow of mouse sickle erythrocytes in vivo. Blood. 2004; 104(10): 3378-3385.

PubMed Abstract | Publisher Full Text

75. Matsui NM, Varki A, Embury SH: Heparin inhibits the flow adhesion of sickle red blood cells to P-selectin. Blood. 2002; 100(10): 3790-3796.

PubMed Abstract | Publisher Full Text

76. Matsui NM, Borsig L, Rosen SD, et al.: P-selectin mediates the adhesion of sickle erythrocytes to the endothelium. Blood. 2001; 98(6): 1955-1962. PubMed Abstract | Publisher Full Text

77. F Kutlar A, Ataga KI, McMahon L, et al:: A potent oral P-selectin blocking agent improves microcirculatory blood flow and a marker of endothelial cel injury in patients with sickle cell disease. Am J Hematol. 2012; 87(5): 536-539. PubMed Abstract | Publisher Full Text | F1000 Recommendation

78. Batchvarova M, Shan S, Zennadi R, et al:: Sevuparin reduces adhesion of both sickle red cells and leukocytes to endothelial cells in vitro and inhibits vaso-occlusion in vivo. Blood. 2013; 122(21): 182-182.

Reference Source

79. Hines PC, Zen Q, Burney SN, et al:: Novel epinephrine and cyclic AMP-mediated activation of BCAM/Lu-dependent sickle (SS) RBC adhesion. Blood. 2003 101(8): 3281-3287.

PubMed Abstract | Publisher Full Text

80. Zennadi R, Hines PC, De Castro LM, et al:: Epinephrine acts through erythroid signaling pathways to activate sickle cell adhesion to endothelium via LWalphavbeta3 interactions. Blood. 2004; 104(12): 3774-3781.

PubMed Abstract | Publisher Full Text

81. Zennadi R, Moeller BJ, Whalen EJ, et al.: Epinephrine-induced activation of LW-mediated sickle cell adhesion and vaso-occlusion in vivo. Blood. 2007; 110(7): 2708-2717

PubMed Abstract | Publisher Full Text | Free Full Text

82. De Castro LM, Zennadi R, Jonassaint JC, et al.: Effect of propranolol as antiadhesive therapy in sickle cell disease. Clin Trans/ Sci. 2012; 5(6): 437-444. PubMed Abstract | Publisher Full Text | Free Full Text

83. Zennadi R, Whalen EJ, Soderblom EJ, et al:: Erythrocyte plasma membranebound ERK1/2 activation promotes ICAM-4-mediated sickle red cell adhesion to endothelium. Blood. 2012: 119(5): 1217-1227. PubMed Abstract | Publisher Full Text | Free Full Text

84. F Soderblom EJ, Thompson JW, Schwartz EA, et al:: Proteomic analysis f ERK1/2-mediated human sickle red blood cell membrane protein phosphorylation. Clin Proteomics. 2013; 10(1): 1 PubMed Abstract | Publisher Full Text | Free Full Text | F1000 Recommendation

85. F Zennadi R: MEK inhibitors, novel anti-adhesive molecules, reduce sickle red blood cell adhesion in vitro and in vivo, and vasoocclusion in vivo. PLoS One. 2014; 9(10): e110306.

PubMed Abstract | Publisher Full Text | Free Full Text | F1000 Recommendation
86. Wolters $\mathrm{HJ}$, ten Cate $\mathrm{H}$, Thomas LL, et al.: Low-intensity oral anticoagulation in sickle-cell disease reverses the prethrombotic state: promises for treatment? Br J Haematol. 1995; 90(3): 715-717.

PubMed Abstract | Publisher Full Text

87. Qari MH, Aljaouni SK, Alardawi MS, et al:: Reduction of painful vaso-occlusive crisis of sickle cell anaemia by tinzaparin in a double-blind randomized trial. Thromb Haemost. 2007; 98(2): 392-396.

PubMed Abstract | Publisher Full Text

88. Ahmed S, Siddiqui AK, Iqbal U, et al:: Effect of low-dose warfarin on D-dimer levels during sickle cell vaso-occlusive crisis: a brief report. Eur $\mathrm{J}$ Haematol. 2004; 72(3): 213-216.

PubMed Abstract | Publisher Full Text

89. Schnog JB, Mac Gillavry MR, Rojer RA, et al:: No effect of acenocoumarol therapy on levels of endothelial activation markers in sickle cell disease. Am J Hematol. 2002; 71(1): 53-55.

PubMed Abstract | Publisher Full Text

90. $\mathrm{F}$ Lee SP, Ataga KI, Zayed M, et al.: Phase I study of eptifibatide in patients with sickle cell anaemia. Br J Haematol. 2007; 139(4): 612-620. PubMed Abstract | Publisher Full Text | F1000 Recommendation

91. F Lee SP, Ataga KI, Orringer EP, et al.: Biologically active CD40 ligand is elevated in sickle cell anemia: potential role for platelet-mediated inflammation. Arterioscler Thromb Vasc Biol. 2006; 26(7): 1626-1631. PubMed Abstract | Publisher Full Text | F1000 Recommendation

92. F Desai PC, Brittain JE, Jones SK, et al.: A pilot study of eptifibatide for treatment of acute pain episodes in sickle cell disease. Thromb Res. 2013. 132(3): 341-345.

PubMed Abstract | Publisher Full Text | Free Full Text | F1000 Recommendation

93. F Wun $\mathrm{T}$, Soulieres $\mathrm{D}$, Frelinger AL, et al:: A double-blind, randomized, multicenter phase 2 study of prasugrel versus placebo in adult patients with sickle cell disease. J Hematol Oncol. 2013; 6: 17.

PubMed Abstract | Publisher Full Text | Free Full Text | F1000 Recommendation

94. Field JJ, Nathan DG, Linden J: Targeting iNKT cells for the treatment of sickle cell disease. Clin Immunol. 2011; 140(2): 177-183. PubMed Abstract | Publisher Full Text | Free Full Text

95. F Field JJ, Lin G, Okam MM, et al:: Sickle cell vaso-occlusion causes activation of iNKT cells that is decreased by the adenosine $A_{2 A}$ receptor agonist regadenoson. Blood. 2013; 121(17): 3329-3334. PubMed Abstract | Publisher Full Text | Free Full Text | F1000 Recommendation

96. Koshy M, Dorn L, Bressler L, et al.: 2-deoxy 5-azacytidine and fetal hemoglobin induction in sickle cell anemia. Blood. 2000; 96(7): 2379-2384.

PubMed Abstract

97. DeSimone J, Koshy M, Dorn L, et al.: Maintenance of elevated fetal hemoglobin levels by decitabine during dose interval treatment of sickle cell anemia. Blood. 2002; 99(11): 3905-3908.

PubMed Abstract | Publisher Full Text

98. $\mathrm{F}$ Terse $\mathrm{P}$, Engelke $\mathrm{K}$, Chan $\mathrm{K}$, et al.: Subchronic oral toxicity study of decitabine in combination with tetrahydrouridine in CD-1 mice. Int J Toxicol. 2014; 33(2): 75-85.

PubMed Abstract | Publisher Full Text | Free Full Text | F1000 Recommendation

99. Kutlar A, Ataga K, Reid M, et al: A phase 1/2 trial of HQK-1001, an oral fetal globin inducer, in sickle cell disease. Am J Hematol. 2012; 87(11): 1017-1021. PubMed Abstract | Publisher Full Text | Free Full Text

100. Kutlar A, Reid ME, Inati A, et al:: A dose-escalation phase lla study of 2,2-dimethylbutyrate (HQK-1001), an oral fetal globin inducer, in sickle cell disease. Am J Hematol. 2013; 88(11): E255-260. PubMed Abstract | Publisher Full Text

101. F Reid ME, El Beshlawy A, Inati A, et al:: A double-blind, placebo-controlled phase II study of the efficacy and safety of 2,2-dimethylbutyrate (HQK-1001), an oral fetal globin inducer, in sickle cell disease. Am J Hematol. 2014; 89(7): $709-713$

PubMed Abstract | Publisher Full Text | F1000 Recommendation

102. Hibbert JM, Hsu LL, Bhathena SJ, et al:: Proinflammatory cytokines and the hypermetabolism of children with sickle cell disease. Exp Biol Med (Maywood). 2005; 230(1): 68-74. PubMed Abstract | Free Full Text

103. Singhal A, Doherty JF, Raynes JG, et al:: Is there an acute-phase response in steady-state sickle cell disease? Lancet. 1993; 341(8846): 651-653. PubMed Abstract | Publisher Full Text

104. F Qari MH, Dier U, Mousa SA: Biomarkers of inflammation, growth factor, and coagulation activation in patients with sickle cell disease. Clin Appl Thromb Hemost. 2012; 18(2): 195-200.

PubMed Abstract | Publisher Full Text | F1000 Recommendation

105. Pathare A, Al Kindi S, Alnaqdy AA, et al:: Cytokine profile of sickle cell disease in Oman. Am J Hematol. 2004; 77(4): 323-328. PubMed Abstract | Publisher Full Text

106. Francis RB Jr, Haywood LJ: Elevated immunoreactive tumor necrosis factor and interleukin-1 in sickle cell disease. J Natl Med Assoc. 1992; 84(7): $611-615$. PubMed Abstract | Free Full Text

107. Graido-Gonzalez E, Doherty JC, Bergreen EW, et al.: Plasma endothelin-1, cytokine, and prostaglandin $\mathrm{E}_{2}$ levels in sickle cell disease and acute vaso-occlusive sickle crisis. Blood. 1998; 92(7): 2551-2555. PubMed Abstract 
108. Michaels LA, Ohene-Frempong $K$, Zhao $H$, et al:: Serum levels of substance $P$ are elevated in patients with sickle cell disease and increase further during vaso-occlusive crisis. Blood. 1998; 92(9): 3148-3151. PubMed Abstract

109. Lanaro C, Franco-Penteado CF, Albuqueque DM, et al.: Altered levels of cytokines and inflammatory mediators in plasma and leukocytes of sickle cell anemia patients and effects of hydroxyurea therapy. J Leukoc Biol. 2009; 85(2): 235-242. PubMed Abstract | Publisher Full Text

110. Brittain JE, Hulkower B, Jones SK, et al.: Placenta growth factor in sickle cell disease: association with hemolysis and inflammation. Blood. 2010; 115(10) 2014-2020.

PubMed Abstract | Publisher Full Text | Free Full Text

111. F Hagag AA, Elmashad G, Abd El-Lateef AE: Clinical significance of assessment of thrombospondin and placenta growth factor levels in patients with sickle cell anemia: two centers Egyptian studies. Mediterr J Hematol Infect Dis. 2014; 6(1): e2014044.

PubMed Abstract | Publisher Full Text | Free Full Text | F1000 Recommendation
112. F Sundaram N, Tailor A, Mendelsohn L, et al.: High levels of placenta growth factor in sickle cell disease promote pulmonary hypertension. Blood. 2010; 116(1): 109-112.

PubMed Abstract | Publisher Full Text | Free Full Text | F1000 Recommendation

113. Perelman N, Selvaraj SK, Batra S, et al:: Placenta growth factor activates monocytes and correlates with sickle cell disease severity. Blood. 2003; 102(4):

1506-1514.
PubMed Abstract | Publisher Full Text

114. F Aslan M, Celmeli G, Özcan F, et al.: LC-MS/MS analysis of plasma polyunsaturated fatty acids in patients with homozygous sickle cell disease. Clin Exp Med. 2015; 15(3): 397-403.

PubMed Abstract | Publisher Full Text | F1000 Recommendation

115. F Garrido VT, Proença-Ferreira R, Dominical VM, et al.: Elevated plasma levels and platelet-associated expression of the pro-thrombotic and pro-inflammatory protein, TNFSF14 (LIGHT), in sickle cell disease. Br J Haematol. 2012; 158(4): 788-797.

PubMed Abstract | Publisher Full Text | F1000 Recommendation 


\section{Open Peer Review}

\section{Current Peer Review Status:}

\section{Editorial Note on the Review Process}

Faculty Reviews are review articles written by the prestigious Members of Faculty Opinions. The articles are commissioned and peer reviewed before publication to ensure that the final, published version is comprehensive and accessible. The reviewers who approved the final version are listed with their names and affiliations.

\section{The reviewers who approved this article are:}

\section{Version 1}

\section{Emily Meier}

Children's National Medical Center, District of Columbia, Washington, 20010, USA

Competing Interests: No competing interests were disclosed.

\section{James G. Taylor VI}

Genomic Medicine Section, Hematology Branch, NHLBI, National Institutes of Health, Bethesda, MD, 20892-1476, USA

Competing Interests: No competing interests were disclosed.

The benefits of publishing with F1000Research:

- Your article is published within days, with no editorial bias

- You can publish traditional articles, null/negative results, case reports, data notes and more

- The peer review process is transparent and collaborative

- Your article is indexed in PubMed after passing peer review

- Dedicated customer support at every stage

For pre-submission enquiries, contact research@f1000.com 